\title{
PENGARUH PEMBERIAN PUPUK KOMPOS KULIT KOPI TERHADAP PERTUMBUHAN DAN HASIL TANAMAN BAWANG MERAH (Allium ascalonicum $L$ ) VARIETAS LEMBAH PALU
}

\author{
Hasnelly, Edi Gatot \\ Program Studi Agroteknologi Fakultas PertanianUniversitas Muara Bungo
}

\begin{abstract}
ABSTRAK
Penelitian ini dilaksanakan di Kebun Desa Tuo Kecamatan Lembah Masurai, selama 3 bulan yang dimulai pada tanggal 01Januari s/d 0231 Maret 2017. Tujuan penelitian ini adalah untuk mengetahui Pengaruh Pemberian Pupuk Kompos Kulit Kopi Terhadap Pertumbuhan dan Hasil Tanaman Bawang Merah (Allium ascalonicum L)" Varietas Lembah Palu, dan untuk mengetahui dosis pupuk kompos kulit kopi yang tepat untuk pertumbuhan dan hasil tanaman bawang merah. Rancangan yang digunakan dalam penelitian ini adalah menggunakan Rancangan Acak Kelompok (RAK) dengan 5 perlakuan dan 4 kelompok yaitu K0 = Tanpa Perlakuan Kompos Kulit Kopi, K1 = 45 g kompos kulit kopi, K2 = 90 g kompos kulit kopi, K3 = 135 g kompos kulit kopi $\mathrm{K} 4=180 \mathrm{~g}$ kompos kulit kopi per petak. Hasil pengamatan dianalisis dengan menggunakan Statistik Analisis Ragam (Anova), apa bila berpengaruh nyata maka dilanjutkan dengan uji Duncan New Multiple Range Tes't (DNMRT) pada taraf $5 \%$. Parameter yang diamati adalah tinggi tanaman $(\mathrm{cm})$, jumlah daun (helai), berat umbi per rumpun (gr) dan Berat Umbi (Ton/ha). Dari hasil penelitian menunjukan bahwa pemberian pupuk kompos kulit kopi berpengaruh nyata terhadap tinggi tanaman $(\mathrm{cm})$, jumlah daun (helai), berat umbi per rumpun (gr) dan Berat Umbi (Ton/ha). Perlakuan terbaik yaitu K2 dengan pemberian perlakuan 90 g kompos kulit kopi
\end{abstract}

Kata Kunci : Kompos Kulit Kopi, Pertumbuhan dan Hasil, Bawang Merah.

\subsection{Latar Belakang}

Bawang merah (Allium ascalonicum L.) adalah salah satu komoditas unggulan di beberapa daerah di Indonesia, yang digunakan sebagai bumbu masakan dan memiliki kandungan beberapa zat yang bermanfaat bagi kesehatan, dan khasiatnya sebagai zat anti kanker dan pengganti antibiotik, penurunan tekanan darah, kolestrol serta penurunan kadar gula darah. Menurut penelitian, bawang merah mengandung kalsium, fosfor, zat besi, karbohidrat, vitamin seperti A dan C.

Hidayat, (2010) Menyatakan bahwa setiap 100 gram umbi bawang merah mengandung $88 \mathrm{~g}$ air, 9,2 g karbohidrat, 1,5 g protein, 0,3 g lemak, 0,03 $\mathrm{mg}$ vitamin $\mathrm{B}, 2 \mathrm{mg}$ vitamin C, $36 \mathrm{mg}$ kalsium, 0,8 $\mathrm{mg}$ besi, $40 \mathrm{mg}$ fosfor, dan 39 kalori.
Bawang merah merupakan salah satu komoditi hortikultura yang termasuk ke dalam sayuran rempah yang digunakan sebagai pelengkap bumbu masakan guna menambah citarasa dan kenikmatan masakan. Di samping itu, tanaman ini juga berkhasiat sebagai obat tradisional, misalnya obat demam, masuk angin diabetes melitus, disentri dan akibat gigitan serangga (Samadi dan Cahyono, 2005)

Kebutuhan terhadap bawang merah terus meningkat seiring bertambahnya jumlah penduduk, namun bawang merah khususnya di Kabupaten Merangin masih didatangkan dari daerah Sumatra Barat dan Jawa. Berdasarkan syarat tumbuh, Merangin khususnya kecamatan Lembah Masurai merupakan daerah dataran tinggi yang sesuai untuk budidaya bawang merah, namun teknik budidayanya masih belum. 
dikembangkan oleh sebab itu perlu adanya penerapan teknik budidaya dan cara pemupukan yang tepat terhadap pertumbuhan bawang merah.

Produktifitas bawang merah Kabupaten Merangin pada Tahun 2014 adalah sebesar $21,39 \mathrm{kw} / \mathrm{ha}$ dari luas panen $44 \mathrm{ha}$. (BPS Jambi 2015). Hasil ini masih sangat rendah jika dibandingkan produktifitas bawang merah yang dibudidayakan secara baik yaitu mampu mencapai hingga 11 ton/ha (Wibowo, 2009).

Untuk meningkatkan produksi bawang merah salah satu hal yang sangat mempengaruhinya adalah ketersediaan unsur hara yang dibutuhkan tanaman, sehingga perlu dilakukan penambahan unsur hara yakni melalui pemupukan (Baswarsiati, 2013).

Selanjutnya hasil penelitian Syahputra dkk, 2013 menyatakan bahwa pemberian kompos kulit kopi 90 g/tanaman mampu memberikan pengaruh nyata terhadap jumlah daun diameter umbi produksi per plot tanaman bawang merah.

Dari uraian latar belakang diatas maka penulis tertarik untuk mengambil judul " Pengaruh Pemberian Pupuk Kompos Kulit Kopi Terhadap Pertumbuhan dan Hasil Tanaman Bawang Merah (Allium ascalonicum L)"Varietas Lembah Palu."

\subsection{Rumusan Masalah}

Apakah pemberian pupuk kompos kulit kopi berpengaruh nyata terhadap pertumbuhan dan hasil tanaman bawang merah (Allium ascalonicum $L)$ ?

1. Pada takaran berapakah pemberian pupuk kompos kulit kopi yang tepat untuk pertumbuhan dan hasil tanaman bawang merah (Allium ascalonicum L)

\subsection{Tujuan Penelitian}

1. Untuk mengetahui pengaruh pemberian pupuk kompos kulit kopi terhadap pertumbuhan dan hasil tanaman bawang merah (Allium ascalonicum L).

2. Untuk mengetahui pada takaran berapakah pemberian pupuk kompos kulit kopi yang tepat untuk pertumbuhan dan hasil tanaman bawang merah (Allium ascalonicum L).

\subsection{Hipotesis}

1. Diduga pemberian pupuk kompos kulit kopi berpengaruh nyata terhadap pertumbuhan dan hasil tanaman bawang merah (Allium ascalonicum L).

2. Diduga pada dosis pemberian pupuk kompos kulit kopi 180 g/tanaman merupakan takaran yang tepat untuk pertumbuhan dan hasil tanaman merah (Allium ascalonicum L).

\section{Tempat dan Waktu Penelitian}

Penelitian ini dilaksanakan di Kebun Desa Tuo Kecamatan Lembah Masurai, yang terletak pada ketinggian $\pm 750-800 \mathrm{~m} \mathrm{dpl}$, dengan suhu $28{ }^{0} \mathrm{C}$ dan $\mathrm{pH}$ tanah 5- 6,5 (Monografi Desa Lembah Masurai).

Penelitian ini dilaksanakan selama 3 bulan, yang akan dimulai pada tanggal 01Januari s/d 31 Maret 2017.

\section{Alat dan Bahan}

Alat yang digunakan dalam penelitian ini diantaranya cangkul, sabit, jangka sorong, bambu, pagar jarring, timbangan digital, penggaris, ayakan dan alat tulis.

Bahan yang digunakan adalah bibit bawang merah varietas Lembah Palu, insektisida, fungisida dan pupuk kompos kulit kopi.

\section{Rancangan Percobaan}

Percobaan ini menggunakan Rancangan Acak Kelompok (RAK) dengan 5 perlakukan dan 4 kelompok yaitu :

$\mathrm{K} 0=$ Tanpa Perlakuan

$\mathrm{K} 1=45 \mathrm{~g}$ kompos kulit kopi per petak $\mathrm{K} 2=90 \mathrm{~g}$ kompos kulit kopi per petak

$\mathrm{K} 3=135$ g kompos kulit kopi per petak

$\mathrm{K} 4=180 \mathrm{~g}$ kompos kulit kopi per petak

Setiap perlakukan dalam percobaan ini diulang 4 kali dengan jumlah petak percobaan adalah 20 petak percobaan. Jarak tanam yang digunakan adalah $15 \times 20 \mathrm{~cm}$ dengan satu tanaman perlubang. Setiap petak terdiri dari 48 tanaman, jadi jumlah tanaman keseluruhan nya sebanyak 960 tanaman Setiap petak diambil 4 
tanaman sebagai sampel, maka jumlah tanaman sampel sebanyak 80 tanaman dengan ukuran petak percobaan $120 \mathrm{~cm}$ x $120 \mathrm{~cm}$ dan jarak antar petak $50 \mathrm{~cm}$.

\section{Parameter yang Diamati :}

Tinggi Tanaman (cm)

Pengamatan tinggi tanaman dilakukan dengan cara mengukur dengan menggunakan penggaris dari ajir sampai pada daun tertinggi dan dikuncupkan. Pengukuran dilakukan mulai tanaman 14 hst hingga 49 hst dengan interval satu minggu satu kali.

\section{Jumlah Daun (Helai)}

Pengamatan jumlah daun dilakukan dengan cara menghitung seluruh daun yang muncul pada tanaman sampel dan di rataratakan. Pengamatan dilakukan 30 hst.

\section{Jumlah Umbi Per Rumpun}

Pengamatan jumlah umbi per rumpun diamati pada umur 70 hst dengan cara menghitung jumlah umbi per rumpun pada tanaman sampel lalu di rata-ratakan

\section{Berat Umbi Per Rumpun (g)}

Pengamatan berat umbi per rumpun dilakukan pada umur 70 hst dengan cara menimbang seluruh umbi pada tanaman sampel dengan menggunakan timbangan digital, selanjutnya dirata-ratakan.

\section{Analisis Data}

Untuk mengetahui pengaruh perlakuan dianalisis secara statistik dengan menggunakan analisis ragam (anova), apabila berpengaruh nyata maka dilanjutkan dengan UjiDuncan New Multiple Range Test (DNMRT) pada taraf 5\%. (Steel and Torrie, 1994).

\section{HASIL DAN PEMBAHASAN}

Rataan tinggi tanaman menurut perlakuan pemberian kompos kulit kopi dapat dilihat pada Tabel 1.
Perlakuan
Tinggi Tanaman

(cm) http://ojs.umb-bungo.ac.id/index.php/saingro/index

\begin{tabular}{lc}
\hline K0 $=$ Tanpa & $19.13 \mathrm{~b}$ \\
Perlakuan & \\
K1 $=45$ g kompos & $23.28 \mathrm{ab}$ \\
kulit kopi & \\
$\mathrm{K} 2=90 \mathrm{~g}$ kompos & $25.06 \mathrm{a}$ \\
kulit kopi & \\
$\mathrm{K} 3=135 \mathrm{~g}$ kompos & $23.68 \mathrm{ab}$ \\
kulit kopi & \\
$\mathrm{K} 4=180 \mathrm{~g}$ kompos & $26.58 \mathrm{a}$ \\
kulit kopi & \\
\hline $\mathrm{KK}=7,05 \%$ &
\end{tabular}

Keterangan :Angka-angka yang diikuti oleh huruf kecil yang berbeda pada kolom yang sama menunjukkan berbeda nyata menurut DNMRT pada taraf $5 \%$.

Dari Tabel 1 diatas dapat dijelaskan bahwa perlakuan (K0) tidak berbeda dengan perlakuan (K1) dan (K3) akan tetapi berbeda dengan perlakuan (K2) dan (K4) hal ini diduga kandungan unsur hara pada kompos kulit kopi dapat terurai dengan baik disebabkan karena melalui proses pengomposan terlebih dahulu sehingga dapat menghasilkan bahan organik yang dapat dimanfaatkan oleh tanaman, disamping itu diduga unsur nitrogen yang terdapat pada kompos kulit kopi yang diserap tanaman salah satu fungsinya adalah membantu pertumbuhan vegetatif tanaman. Sedangkan aktivitas mikroorganisme dapat membantu pertumbuhan tanaman dan mempengaruhi kesuburan tanah melalui perannya memperlancar siklus unsur hara dan menyuplai hormon-hormon serta enzim yang berguna bagi pertumbuhan tanaman

Proses pengomposan adalah suatu proses mikrobiologi. Bahan organik dirombak oleh aktivitas mikroorganisme sehingga dihasilkan energi dan unsur karbon sebagai pembangun sel-sel tumbuh yang menyebabkan hormon auksin bekerja secara maksimal sehingga tanaman bawang merah tumbuh lebih cepat atau mengalami etiolasi sedangkan tanaman yang banyak mendapat cahaya matahari menyebabkan kerja hormon auksin terhambat sehingga tanaman tumbuh lebih lama (Haryani, $d k k$ 2010). 
Selanjutnya menurut Hardjowigeno (1995), bahwa bahan organik dapat memperbaiki sifat fisik, kimia dan biologi tanah. Sifat fisik tanah menyebabkan perkembangan perakaran menjadi lebih baik sehingga dapat mengabsorbsi unsur hara oleh tanaman dalam kondisi unsur hara yang baik maka penyerapan unsur hara berjalan maksimal sehingga pertumbuhan berjalan optimum.

Pemberian bahan organik juga dapat mempengaruhi sifat kimia tanah yaitu dapat meningkatkan $\mathrm{pH}$ tanah. Menurut Buckman dan Brady (1982), bahwa pH tanah dapat mempengaruhi ketersediaan unsur hara. artinya $\mathrm{pH}$ tanah selama penelitian diduga sesuai untuk pertumbuhan dan perkembangan tanaman bawang merah sehingga unsur hara di dalam tanah menjadi tersedia dan bisa diserap oleh tanaman. Pemberian kompos kulit buah kopi juga dapat memperbaiki sifat biologi tanah dengan meningkatkan aktivitas mikroorganisme tanah.

\section{Jumlah Daun (Helai)}

Untuk melihat rataan luas daun total pada perlakuan pemberian pupuk kompos kulit kopi dapat dilihat pada Tabel 2.

Tabel 2. Rataan Jumlah Daun (helai) dengan Perlakuan Pupuk Kompos Kulit Kopi

\section{Perlakuan}

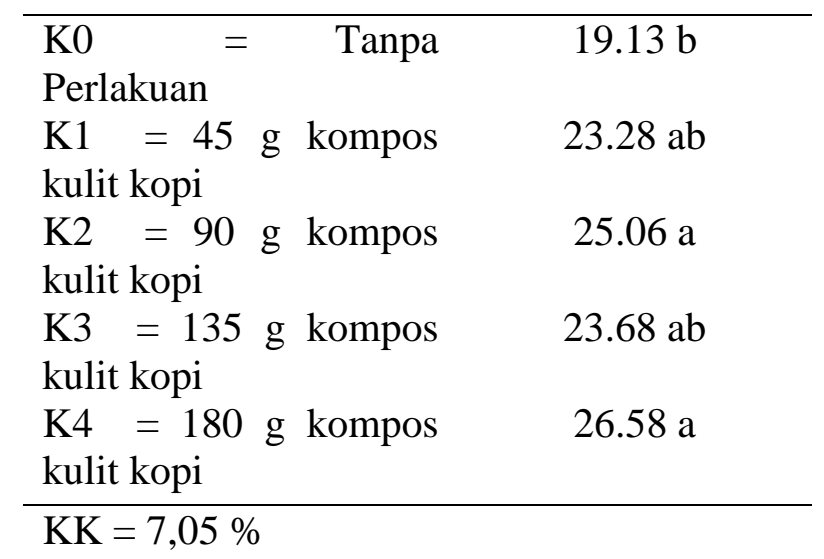

Keterangan :Angka-angka yang diikuti oleh huruf kecil yang berbeda pada kolom yang sama menunjukkan berbeda nyata menurut DNMRT pada taraf $5 \%$.
Pada Tabel 2. Dapat dilihat perlakuan (K0) tidak berbeda dengan perlakuan (K2), akan tetapi tidak berbeda dengan perlakuan (K1), (K3) dan (K4). Perlakuan (K1) merupakan perlakuan terbaik terhadap jumlah daun hal ini diduga tersedianya kandungan unsur hara dari perlakuan yang diberikan dapat meningkatkan jumlah daun tanaman. jumlah daun dapat meningkatkan proses fotosintesis tanaman. Proses fotosintesis yang terjadi pada bagian daun menghasilkan fotosintat yang selanjutnya ditranslokasikan ke bagian tanaman yakni batang, akar dan daun.

Ramli $d k k$ (2008), menyatakan Proses fotosintesis yang terjadi pada bagian daun menghasilkan fotosintat yang selanjutnya ditranslokasikan ke bagian tanaman yakni batang, akar dan daun, hasil fotosintat pada tanaman petsai saat pertumbuhan vegetatif ditranslokasikan ke bagian daun yang selanjutnya digunakan untuk menambah jumlah daun. Namun demikian penambahn jumlah daun juga dipengaruhi oleh berbagai faktor seperti seperti sifat fisik dan kimia tanah termasuk ketersediaan unsur hara. Pertambahan jumlah daun tanaman selama pertumbuhan merupakan sifat tanaman.

Menurut Hardjowigeno (1995), bahan organik akan memperbaiki struktur tanah dan menambah kemampuan tanah menahan unsur hara seperti N, P, K dan unsur lainnya berlangsung baik dan meningkatkan KTK tanah. Terciptanya struktur tanah yang baik karena pemberian kompos kulit buah kopi akan menyebabkan akar tanaman menjadi lebih mudah menembus tanah dan berkembang cepat membentuk cabang-cabang akar serta tersedianya unsur hara di dalam tanah menyebabkan akar aktif berkembang.

Menurut Sutejo dan Kartasapoetra (2008), bahwa untuk perkembangan sistem perakaran tanaman diperlukan unsur $\mathrm{N}$ dan $\mathrm{P}$ yang merupakan bagian dari protoplasma dan inti sel. Sebagai bagian dari inti sel, unsur tersebut sangat penting dalam pembelahan sel dan perkembangan jaringan meristematik dan unsur $\mathrm{K}$ berperan dalam menambah pembentukan 
karbohidrat. Menurut Gardner dkk (1991), bahwa pertumbuhan dan perkembangan akar yang sempurna membutuhkan penyerapan air dan hara yang optimal sehingga dapat merangsang pertumbuhan jumlah daun tanaman.

Jumlah daun sangat dipengaruhi oleh kandungan $\mathrm{N}$ tanaman karena $\mathrm{N}$ merupakan salah satu penyusun utama klorofil (Taiz dan Zeiger, 1998). Kandungan $\mathrm{N}$ yang terdapat di dalam kompos kulit buah kopi mampu menambah jumlah klorofil pada daun tanaman bawang merah dan berbeda nyata dibandingkan dengan jumlah klorofil tanpa pemberian kompos kulit buah kopi.

Diyah, (2013), mengatakan bahwa pupuk kompos kulit kopi mengandung unsur kalium yang berperan penting dalam setiap proses metabolisme tanaman, yaitu dalam proses sintesis asam amino dan protein dari ion-ion ammonium serta berperan memelihara tekanan turgor dengan baik sehingga memungkinkan lancarnya proses-proses metabolisme dan menjamin kesinambungan pemanjangan sel.

\section{Berat Umbi Per Rumpun (g)}

Rataan Berat Umbi Per Rumpun (g) menurut perlakuan pemberian kompos kulit kopi dapat dilihat pada Tabel 3

Tabel 3. Rataan Berat Umbi Per Rumpun (g) dengan Perlakuan Pupuk Kompos Kulit Kopi

\section{Perlakuan}

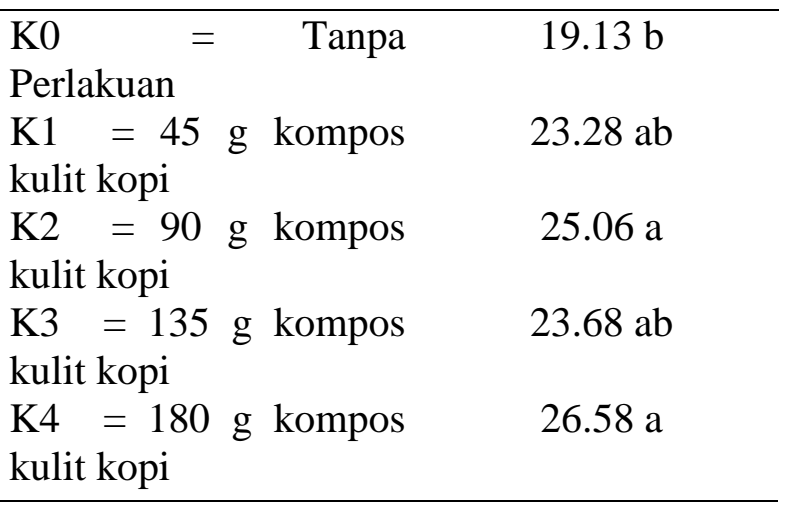

$$
\mathrm{KK}=7,05 \%
$$

Keterangan :Angka-angka yang diikuti oleh huruf kecil yang berbeda pada kolom yang sama menunjukkan berbeda nyata menurut DNMRT pada taraf $5 \%$.

Dari Tabel diatas dapat dijelaskan bahwa perlakuan control (K0) tidak berbeda dengan perlakuan (K1), akan tetapi berbeda dengan perlakuan (K2), (K3) dan (K4). Perlakuan terbaik terhadap berat umbi per rumpun yaitu (K2) dengan pemberian perlakuan 90 g kompos kulit kopi. Hal ini disebabkan kompos kulit kopi dapat memperbaiki struktur tanah, menyediakan unsur hara bagi tanaman sehingga tanaman dapat tumbuh secara optimal dan dapat memacu absorbsi air dan hara karena semakin memperluas permukaan kontak antara akar dan tanah. Hal ini sesuai dengan literatur (Pujiyanto, 2005) yang menyatakan bahwa limbah kulit buah kopi memiliki kadar bahan organik dan unsur hara yang memungkinkan untuk memperbaiki sifat tanah. Hasil penelitian menunjukkan bahwa kadar C-organik kulit buah kopi adalah 45,3\%, kadar nitrogen 2,98 $\%$, fosfor $0,18 \%$ dan kalium 2,26\%. Selain itu kulit buah kopi juga mengandung unsur $\mathrm{Ca}$, $\mathrm{Mg}, \mathrm{Mn}, \mathrm{Fe}, \mathrm{Cu}$ dan $\mathrm{Zn}$. Dalam 1 ha areal pertanaman kopi akan memproduksi limbah segar sekitar 1,8 ton setara dengan produksi limbah kering $630 \mathrm{~kg}$.

Nitrogen yang terkandung dalam kompos berperan sebagai penyusun protein sedangkan fosfor dan kalsium berperan dalam memacu pembelahan jaringan meristem dan merangsang pertumbuhan daun dan akar, akibatnya tingkat absorpsi unsur hara dan air oleh tanaman sampai batas optimumnya akan digunakan untuk pembentukan umbi dan diferensiasi sel (Ayub, 2010)

Kalium mengatur kegiatan membuka dan menutupnya stomata, Pengaturan stomata yang optimal akan meningkatkan transpirasi tanaman meningkatkan reduksi karbondioksida yang akan dirubah menjadi karbohidrat Unsur hara nitrogen, fosfor dan kalium serta unsur mikro yang terkandung dalam kompos kulit kopi akan menghasilkan aktivitas fotosintesis tanaman 
sehingga meningkatkan karbohidrat yang dihasilkan sebagai cadangan makanan untuk tanaman dalam pembentukan umbi. Hal ini sesuai dengan peryataan Purwowidodo (1992) bahwa protein merupakan penyusun utama protoplasma yang berfungsi sebagai pusat metabolisme dalam tanaman yang selanjutnya akan memacu pembelahan dan pemanjangan sel. Unsur hara nitrogen dan unsur hara mikro tersebut berperan sebagai penyusun klorofil sehingga menigkatkan aktifitas fotosintesis dan akan menghasilkan fotosintat yang akan mengakibatkan perkembangan pada jaringan, pada saat fotosintat meningkat maka protein akan tersusun dan berfungsi untuk pembentukan umbi-umbi baru.

\section{.Kesimpulan}

\section{KESIMPULAN DAN SARAN}

1. Pemberian Pupuk kompos kulit kopi berpengaruh nyata terhadap tinggi tanaman, jumlah daun, berat buah per rumpun dan berat umbi (ton/ha).

2. Perlakuan terbaik terhadap pertumbuhan dan hasil tanaman bawang merah yaitu $\mathrm{K} 2$ dengan dosis $90 \mathrm{~g} /$ petak.

\section{Saran}

Untuk mendapatkan produksi bawang merah yang optimal diharapkan menggunakan takaran (K2) dosis $90 \mathrm{~g} /$ petak.

\section{DAFTAR PUSTAKA}

Adam M. dan Prayitno 2012. Hasil Analisis Proksimat Bahan Asal Limbah Pertanian. Laporan tahunan. Universitas Andalas. Padang

Ayub, P. 2010. Meningkatkan Hasil Panen Dengan Pupuk Organik. Jakarata: Agromedia Pustaka.

Badan Pusat Statistik Provinsi Jambi. 2015. Produktifitas Tanaman Sayuran dan Buah-Buahan.Jambi.

Baswarsiati, R 2013. Pengkajian Agribisnis Bawang Merah. Agromedia Jakarta
Berlian Z, Syarifah1, Devi, Selvia S. 2013. Pengaruh Pemberian Limbah Kulit Kopi (Coffea robusta L.) Terhadap Pertumbuhan Cabai Keriting (Capsicum annum L.). FPMIPA IKIP. Mataram.

Buckman, H. O dan N. C. Brady. 1982. Ilmu Tanah. Terjemahan Soegiman. Bharat Karya Aksara. Jakarta.

Diyah. 2013. Kandungan Unsur Hara Pupuk Kompos Limbah Pertanian. Agromedia Jakarta.

Gardner, F. P, B. Pearce dan R. L. Mitchell. 1991. Fisiologi Tanaman Budidaya. Universitas Indonesia. Jakarta

Hardjowigeno, S. 1995. Ilmi Kesuburan Tanah. Akademi Pressindo. Jakarta

Haryani, D.S., Dewi I.N., Mirawati B. 2010. Pengaruh Pemberian Limbah Kulit Kopi Terhadap Pertumbuhan Vegetatif Kacang Tanah (Arachis hypogaea L.) Dalam Upaya Pembuatan Brosur Bagi Masyarakat

Hidayat, H. 2010. Manfaat Budidaya Bawang Merah, Balai Penelitian Tanaman sayuran, Jakarta.

Marsono dan Paulus, S. 2005. Pupuk Akar dan Jenis Aplikasi. Penebar Swadaya. Jakarta.

Munawar, A. 2011. Kesuburan Tanaman dan Nutrisi Tanaman. IPB Press. Bogor

Pitojo, 2013. Bawang Merah. Penebar Swadaya. Jakarta.

Pujiyanto. 2005. Pemanfaatan Kulit Buah Kopi dan Bahan Mineral Sebagai Amelioran Tanah Alami. ,Jurnal Fakultas Pertanian, Universitas Brawijaya, Malang. 
Poewowidodo. 1992. Telaah KesuburanTanah. Penerbit Angkasa. Bandung

Ramli, Dwi Z, Mulyadi S. 2011. Pengaruh Kompos Kulit Buah Kopi Terhadap Pertumbuhan Dan Hasil Tanaman Petsai Pada Tanah Aluvial. Universitas Tanjung Pura. Pontianak.

Rismunandar, 2009.Menbudidayakan 5 Jenis Bawang. Sinar Baru, Bandung.

Rosmarkam, A. dan Nasih, V. Y. 2002. Ilmu Kesuburan Tanah. Kanisius. Yogyakarta

Rukmana, E 2004 Teknik Pelaksanaan Kegiatan Efikasi Zat Perangsang Tumbuh Pada Bawang Merah. Buletin Teknik Pertanian.

Samadi dan Cahyono, 2005. Pedoman

Bertanam Bawang, Kanisius, Yogyakarta.

Sudirja, 2010. Bawang Merah. http//www.lablink.or.id/Agro/bawangmr h/ Alternaria partrait.html diakses 30 Oktober 2016.

Sumarni, N, dan Hidayat, A., 2005. Panduan Teknis Budidaya Bawang Merah. Balai Penelitian Tanaman Sayuran. Lembang.

Suriani L. 2011. Pedoman Budidaya Bawang Merah. Kanisius Yokyakarta.

Surojo G, 2006, Pemupukan dan Pemeliharaan Bawang Merah, Dipertabun, Nganjuk. Jurnal Online Agroekoteknologi ISSN No. 2337- 6597. Agroekoteknologi Fakultas Pertanian USU. Medan.

Sutedjo dan Kartasapoetra. 2008. Pupuk Dan Cara Pemupukan. Bina Aksara. Jakarta

Syahputra A. Barus, A, Sipayung R. 2013. Pertumbuhan Dan Produksi Bawang Merah (Allium ascalonicum .L) Terhadap Pemberian Kompos Kulit Kopi Dan Pupuk Organik Cair.
Agroekoteknologi Fakultas Pertanian USU, Medan

Taiz, L dan E. Zeiger. 1998. Plant physiology. Third Edition Sinauer Associates Inc. Publishers. Massachusets.

Wibowo D. 2009. Pedoman Bertanam Bawang, Kanisius, Yogyakarta.

Wulandari, V. 2011.Pengaruh Pemberian Beberapa Pupuk Organik Pertumbuhan Dan Hasil Tanaman Rosella (Hibiscus sabdariffa L) di Tanah Ultisol.Padang : Fakultas Pertanian Universitas Andalas Padang. 